\title{
The Research of Service Quality Evaluation System Based on SERVQUAL
}

\author{
SHEN Hong ${ }^{1,2, a}$ \\ ${ }^{1}$ Wuhan Electric Power Technical College, Wuhan 430079, China \\ ${ }^{2}$ HBEPC Technology Training Center, Wuhan 430079, China \\ ashenhong@163.com
}

Keywords: Service Quality Evaluation, SERVQUAL, Quality Management

\begin{abstract}
As people's living standard and service consciousness constantly improve, the types of services are diversified and multi-level trend, the competition between service not only reflected in the service project, reflect more on the quality of service. Now part of the organization often only pay attention to economic benefits, and ignore the quality of service, telephone customer service system. To continue to improve service quality, telephone customer service staff evaluation and management of the quality of service has become the core and focus of the service. Therefore, we need to establish a scientific and objective, can reflect actual feelings and expectations of customers service quality evaluation model, evaluation and forecast customer service requirements, examines the existing service quality, while the SERVQUAL evaluation method can meet the above requirements.
\end{abstract}

\section{Introduction}

Service quality is the primary factor in the service market competition, not only directly related to the customer's demand, and is the first requirement of service organization to survive. To continue to improve service quality, evaluation and management of the quality of service has become the core and focus of the service. In the "customer-oriented" service concept, should empower customers to participate in service quality evaluation. International services more esteem the SERVQUAL evaluation method is by understanding customer expectation and perception of evaluation objects, to judge the quality of service. Compared with the degree of satisfaction evaluation, can know more information about perception and expectations, and evaluation result is more objective and true. But the construction of a telephone customer service SERVQUAL service quality evaluation system is still rare study [1-2]. Therefore, combined with the particularity of service industry, telephone customer service based on SERVQUAL telephone customer service quality evaluation model, evaluation and predict customer service requirements, examines the existing telephone customer service quality, has the certain innovation and the important practical significance.

Based on the study of telephone customer service quality evaluation model based on SERVQUAL, preliminary establish suitable for China's telephone customer service industry, scientific and reasonable, the service quality evaluation model based on SERVQUAL evaluation method, including the composition of indicators of the evaluation questionnaire, to call customer service to understand the demand of customers, evaluate its service quality, improve the service quality to provide a tool. In addition, through understanding the basic situation of the customer to the service quality evaluation, the influence of a deeper understanding of the evaluation model.

\section{SERVQUAL evaluation model}

SERVQUAL evaluation method in 1988, is put forward by the service marketing experts LLBerry, AParasuraman, and VAZeithaml, it is designed for service organization one complete set of service quality objective evaluation tools used to measure customer perceived quality [3]. By studying how the determinants of service quality and customer service quality perception and so on, that five 
factors in determining the quality of service are: reliability, responsiveness, assurance, empathy, tangibles, as shown in figure 1. SERVQUAL method based on the above five determinants, through the gap between expectation and customer experience of customer service of the comparative analysis to measure. SERVQUAL model is widely used in service industry, in order to understand the target customer service requirements and perception, and provide enterprises with a set of management and measure method of the quality of service. Within the enterprise, using the SERVQUAL model to understand the employees' perception of service quality, so as to achieve the goal of improve the service [4].

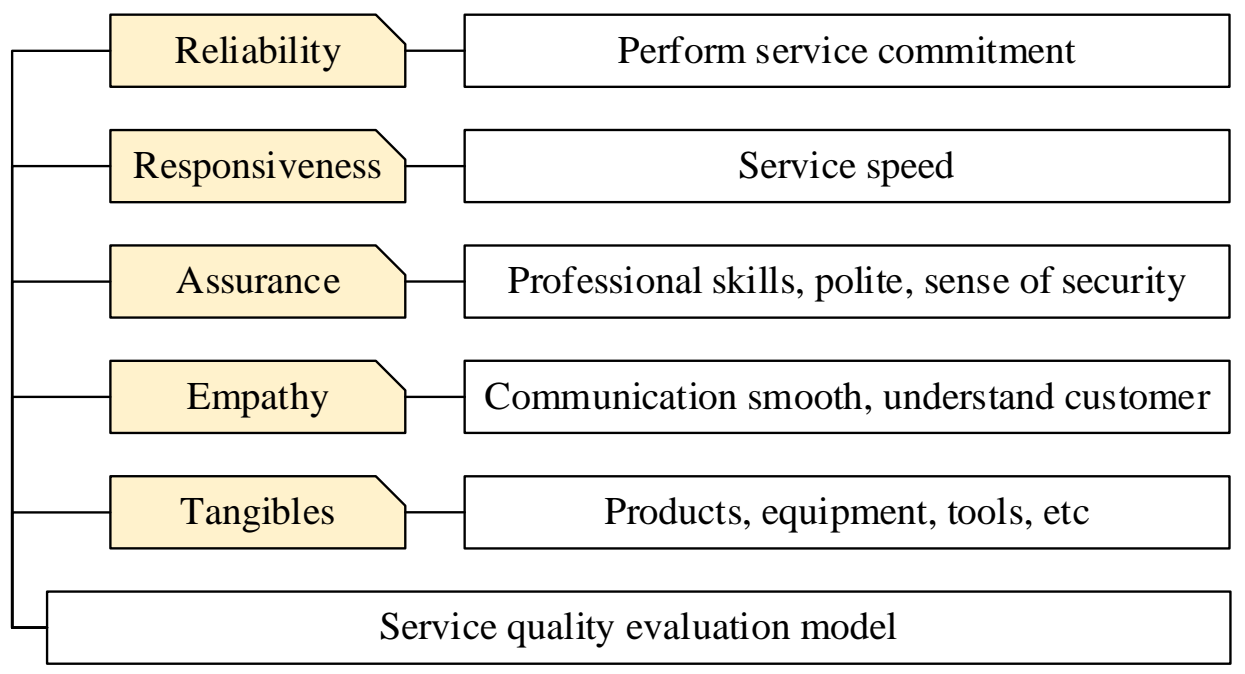

Figure 1 . The five factors in determining the quality of service

It usually selects 22 indexes, respondents according to their service experience to answer questions (each index score between 1 and 7, respectively "completely agree" and "completely disagree") to show their expectations of service quality and perception of service quality, and customer can accept the lowest quality of service), thus to determine the total score of perceived service quality. The higher the score, the farther indicates that customer service experience and the expected distance, namely customer perception of service quality is lower [5]. SERVQUAL as one kind of comprehensive measuring tool, can be used to understand the shipper for carriage of goods by rail service quality expectations, and measure the gap between expectation and reality of the owner, the evaluation result can be used for the comparison of different enterprise quality, enterprise itself should be how to improve the service level, new service standards should be how to determine and so on, is a good measure so that the railway goods transportation service quality evaluation method.

\section{Service quality evaluation process research}

Customer satisfaction is not just a customer service strategy, and is the strategy of telephone customer service enterprise, it also reflects the customer a kind of consumer psychology, is the customer consumption experience compared with their own expectations, so the customers with quality service for telephone customer service staff demand is higher and higher, and requirements including the whole process of production and service to satisfy our customers, so as to establish an optimized evaluation mechanism of service management, service quality, quickly and efficiently reflect and improve the service level is the enterprise the key to customer satisfaction. Based on improving customer satisfaction evaluation system, to research customer satisfaction evaluation system, form the evaluation improved after operation, at the same time, facing the vast amounts of customer data, using data mining techniques for customer satisfaction evaluation, mining, power generation enterprises to scientifically guide the marketing process of ascension important indicator, to adjust business strategy, improve customer loyalty, satisfaction, reduce customer churn. Service quality evaluation can be based on SERVQUAL evaluation model, according to the personality 
characteristics of the service organizations to implement, the total way of thinking as shown in figure 2 .

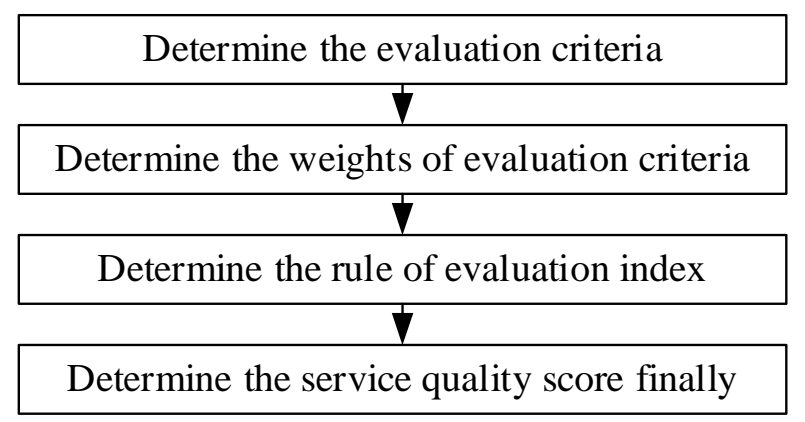

Figure 2. The overall process of service quality evaluation

\section{The building of service quality evaluation model architecture based on SERVQUAL}

After the system management, staff and customers in-depth interviews, this article preliminary conclusion based on the SERVQUAL service quality evaluation model, as shown in figure 3. According to the theory of customer perception of service quality, service quality can be defined as: the extent of the services meet or exceed their expectations, the perception of service quality and the extent of the expected service quality conform, it reflects the degree of customer satisfaction. For a customer, he will be how to evaluate the service quality? Due to the quality of customer perception of service quality is divided into functional and technical quality, customers will be from the two aspects carries on the appraisal. For services, the function in the process of quality refers to the service quality, customer is in the process of receiving services through the feelings of the appearance of the image and service attitude, behavior, instrument and so on need to meet and enjoy. Technical quality refers to the service to its customers' body and mind change, refers to the result of the service to satisfy customers.

Here, telephone customer service, for example, it is a kind of service for the customer, on behalf of the company through the telephone communication with the customers maintain a quick and easy way. Telephone customer service quality is important, it reflects the enterprise's service quality, also reflects the enterprise working attitude. Call service quality evaluation index system can be divided into the service quality evaluation, the service specification evaluation, consulting services, training evaluation, supervision and evaluation of complaints.

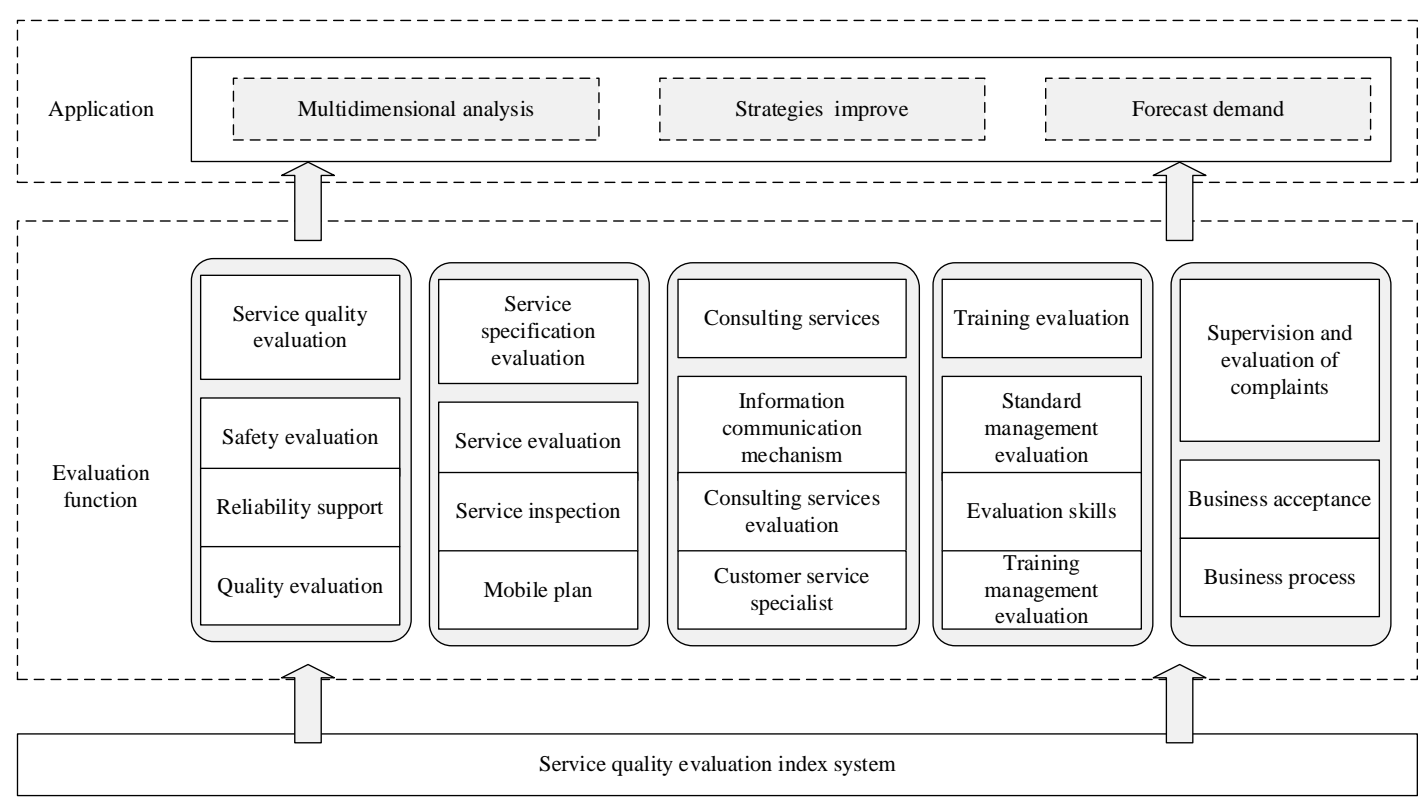

Figure 3. The service quality evaluation model architecture based on SERVQUAL 
The proposed evaluation model to try to achieve the four "combined" : first, from the perspective of customers, the expectations of the service and the quality of service of actual feelings combined two aspects; Second, the quality of the evaluation function of service and technical quality two aspects; Third, the structure of the content of the evaluation of the service quality, process quality and outcome quality combining the three links; Fourth, the evaluation of the object to realize combining the evaluation of layers of management and employees. Therefore, the application of this evaluation model to evaluate the service quality will promote the comprehensive quality management.

\section{Conclusion}

With the deepening of the process of our reform and opening up, more and more people realize the importance of service to the survival and development organization, services in the economic developed countries enterprises occupy very important position. Evaluation of the quality of service and management is the core and key continuously improve the quality of service. International services have been widely adopted SERVQUAL evaluation method to judge the service quality of high and low, but to build our own SERVQUAL hotel service quality evaluation system is still in the initial phase of research. In this paper, based on the SERVQUAL scale, on the basis of quality characteristics of service industry, to select and combine relevant variables, preliminary build the suitable for telephone customer service industry, service quality evaluation system, the SERVQUAL evaluation method was applied to the evaluation of service quality in is feasible, but the evaluation criteria and sub criteria selection should reflect the features of the service itself. Based on the SERVQUAL service quality evaluation, help enterprises improve the quality of our products.

\section{References}

[1] A. Awasthi, S.S. Chauhan, H. Omrani: Computers \& Industrial Engineering, Vol.61(2011) No.3, p. 637.

[2] J.I. Shieh, H.H. Wu, K.K. Huang: Knowledge-Based Systems, Vol.23(2010) No.3, p. 277.

[3] H. Landrum, V. Prybutok, X. Zhang: Informing Science: the International Journal of an Emerging Transdiscipline, Vol.12(2009) No.1, p. 17.

[4] G. Büyüközkan, G. Çifçi: Expert Systems with Applications, Vol.39(2012) No.3, p.2341.

[5] R. Ladhari: International Journal of Quality and Service Sciences, Vol.1(2009) No.2, p. 172. 